ORIGINAL ARTICLE

AFRICAN JOURNAL OF CLINICAL AND EXPERIMENTAL MICROBIOLOGY SEPTEMBER 2013 ISBN 1595-689X VOL14 No.3

AJCEM/1322

COPYRIGHT 2013

http://www.ajol.info/journals/ajcem

AFR. J. CLN. EXPER. MICROBIOL. 14(3): 127-133 http:/ / dx.doi.org/10.4314/ajcem.v14i3.2

\title{
RISK FACTORS FOR HEPATITIS C VIRUS ANTIBODY SEROPOSITIVITY AMONG CHILDREN WITH SICKLE CELL ANAEMIA IN ILORIN, NIGERIA.
}

\author{
${ }^{*}$ Onuchukwu, C.E., +Ojuawo, A. \& +Ernest, S.K++.
}

*Department of Paediatrics and Child Health, Federal Medical Centre P.M.B. 004, Keffi, Nasarawa State. +Department of Paediatrics and Child Health, University of Ilorin Teaching Hospital, Ilorin, Kwara State.

++Correspondence: Ernest, S.K., Department of Paediatrics and Child Health, University of Ilorin Teaching Hospital, Ilorin, Kwara State. E mail: skernest2003@yahoo.com

\begin{abstract}
Background: Hepatitis $\mathrm{C}$ is an infectious disease of the liver caused by the hepatitis $\mathrm{C}$ virus (HCV) resulting to a chronic hepatitis. Chronic HCV infection constitutes a serious public health challenge in Nigeria where donor blood is not routinely screened for HCV. Patients with sickle cell anaemia (SCA) are considered a subset of the population at higher risk of acquiring the virus, due to their frequent needs for transfusion of blood and its products. Other risk factors like scarification markings, tattooing, and circumcision also predispose children to acquiring this infection. However, the magnitude of HCV infection has not been adequately measured in our general population and specific data on HCV in SCA patients are scanty, hence a prospective case controlled study to determine the risk factors that predispose to the acquisition of hepatitis $C$ Virus infection.

Objective: To determine the risk factors for Hepatitis C Virus Antibody Seropositivity among transfused children with SCA in Ilorin.

Subjects and Method: Eighty two transfused SCA children aged 6 months to 14 years were recruited consecutively from February 2008 to January 2009 while eighty four non transfused SCA children of the same age range recruited over the same period served as controls. Hepatitis C virus Antibody screening was done using a second generation ELISA method. Information on the study population were collected by use of a pretested questionnaire by the investigator.

Results: There was a positive correlation between numbers of units of blood transfused and seropositivity. Those who had three or more units of blood had a prevalence rate of more than $50 \%$. There was a strong correlation between seropositivity and scarification marks in both subjects and controls $(p=0.001$ and 0.02 respectively). Other plausible risk factors for hepatitis $C$ infection tested in this study included circumcision and sharing of clippers which showed no statistically significant difference. No cases of tattooing, drug abuse, needle sharing or sexual activities were seen in this study. Conclusion: Transfused SCA patients belong to a high risk group for hepatitis $C$ virus infection compared to the nontransfused population. The risk of acquisition increases with higher number of transfusions and scarifications marks.
\end{abstract}

Key words: Hepatitis C virus, Sickle cell anaemia, Risk factors, Blood transfusion.

\section{INTRODUCTION}

The Hepatitis $\mathrm{C}$ virus (HCV) has become an important cause of chronic liver disease and liver cancer worldwide(2). Hepatitis C Virus infection is highly prevalent in Africa, however the epidemiology of this infection is yet to be well defined (1). Hepatitis $C$ virus infection has been found to lead to chronicity in $70-85 \%$ of cases(3), which is similar to hepatitis B virus infection (HBV) which becomes chronic in about $75 \%$ of individuals infected (4). It is estimated that about 170 million people worldwide are chronically infected with HCV and majority are in developing countries. ${ }^{5}$ About $30 \%$ of those infected with $\mathrm{HCV}$ will progress to liver cirrhosis and ultimately to end stage liver failure and hepatic carcinoma $(3,4,6)$. It is one of the agents transmissible by blood transfusion and is now known to be the major cause of non-A, non-B post transfusion hepatitis (NANBH) (7). The risk factors that are associated with transmission of both $\mathrm{HCV}$ and HBV infections are transfusion of blood and blood products, tattooing, scarification with re-usable instruments, body piercing, injection/illicit drug use, perinatal transmission and multiple sex partners $(5,8)$. Since HCV was first identified $(9,10)$, one of the best known and most extensively studied routes of its transmission has been blood and blood derivative transfusion $(11,12)$, therefore patients at risk for $\mathrm{HCV}$ infection include transfusion dependent Haemophiliacs, homozygous $\beta$-Thalassaemia and sickle cell anaemia (SCA) patients (13).

The commonest condition in Nigeria for which patients receive repeated blood transfusion is SCA (14)., which has a prevalence of $1.6-3 \%$ in Nigeria (15).

In Japan, unsafe injections as in the use and re-use of unsterilized needles in the practice of acupuncture and related techniques have been documented as significant routes of $\mathrm{HCV}$ transmission (2). Kaine et al (16) estimated that 2.3 to 4.7 million $\mathrm{HCV}$ infections annually might be caused by similar unsafe injections in developing countries.

In Nigeria, patients with Sickle Cell Anaemia (SCA) represent the group most likely to receive multiple blood transfusions. Severe anaemia crisis often complicated by malaria parasitaemia and other 
infections constitute the major indications for blood transfusion (2). The risk of transfusion acquired $\mathrm{HCV}$ infection and its potentially devastating consequences are clearly greater in this environment where re-donor HCV screening is not standard practice (2).

In the present study, we hope to estimate the role of blood transfusion and other risk factors in the transmission of $\mathrm{HCV}$ infection.

\section{SUBJECTS AND METHODS}

The study was carried out at the University of Ilorin Teaching Hospital (UITH) Ilorin, Nigeria. The hospital has a well established sickle cell clinic that serves the north-central and south-west Nigeria. The University of Ilorin Teaching Hospital (U.I.T.H.) is a tertiary health facility that serves as a referral centre for Kwara, Kogi, Niger, Osun and Ekiti States of Nigeria and also offers secondary health services to the public. It runs a wellestablished Sickle Cell Disease Clinic for patients below the age of 14 years. An average of 30 mainly old and few new patients are seen in the clinic every Monday. On attaining the age of 14 years such individuals are transferred to the adult Sickle Cell Disease Clinic of the same hospital. The hospital provides a blood transfusion service and laboratory that screens blood for antibodies to $\mathrm{HCV}$.

Eighty-two transfused SCA children aged 6 months to 168 months were recruited consecutively from February 2008 to January 2009 while 84 non transfused SCA children of the same age range recruited over the same period served as controls. Antibodies to $\mathrm{HCV}$ screening were done using a second generation ELISA method. The age of the subjects in this study were taken as their completed months at recruitment. The subjects were transfused at least 6 months before presentation to be eligible for the study.

Haemoglobin $(\mathrm{Hb})$ electrophoresis was carried out using electrophoretic tank (Volkman SAE 2761) with cellulose acetate paper at $\mathrm{pH} 8.4$ to confirm their status in the Haematology department of U.I.T.H Ilorin. A pretested questionnaire was used to obtain information on age, sex, history of blood transfusion, parents' educational level as well as occupation to obtain their social class.

Ethical clearance was obtained from the Ethical Review Committee of the hospital and official permission obtained from the head of the Haematology Department. After a clear explanation of the project to them, informed consent was also obtained from either or both parents/guardian and the children before subject enrolment.

Five milliliters of venous blood was collected fromeach subject after a verbal consent and then transported to the laboratory where the serum was separated and assayed for antibodies to HCV immediately using a $2^{\text {nd }}$ generation HCV one step hepatitis $C$ virus test strip manufactured by Acumen diagnostic incorporated, USA ${ }^{112}$ which is a Rapid Chromatographic Immunoassay for the qualitative detection of antibody to $\mathrm{HCV}$ in serum was used for HCV analysis._The sensitivity and specificity of the test strip were $99.6 \%$ and $99.5 \%$ respectively.

Statistical analysis was done using SPSS statistical package. The chi-square test was used to assess the significance of the difference amongst the groups and a p-value of $<0.05$ was considered significant.

\section{RESULTS}

A total of 82 transfused sickle cell anaemia patients and 84 non-transfused sickle cell anaemia patients were recruited into the study. The male to female ratio was 1.6:1 in the subjects and 1.1:1 in the controls. The mean age of the subjects and the controls were 95.8+ 48.7 months and $93.5+54.0$ months respectively and are comparable $(\mathrm{p}=0.77)$. Table I. Table II shows that five of the children had detectable antibodies to $\mathrm{HCV}$, constituting $3 \%$ of the total population studied, giving an overall hospital-based prevalence of Hepatitis $\mathrm{C}$ infection in sickle cell anaemia (SCA) to be $3 \%$. The prevalence of anti-HCV in both the subjects and the controls were comparable $(p=0.68)$, as shown in Table II below.

Table III shows that the subjects and controls were comparable in terms of social stratification in classes I, IV and V, but more controls were in social classes II and more subjects in social class III in the subjects ( $p=0.003$ and 0.002 for classes II and III respectively). There is no significant difference in the seroprevalence of HCV infection in the low and high social classes, (Table IV) both in the subjects and controls.

Table V shows that among the subjects, anti-HCV seropositivity increased with the number of units of blood transfused. This increase was such that $2.2 \%$ of recipients of 1-2 units and $6.9 \%$ of recipients of 34 units were anti-HCV positive.

All the subjects received blood transfusion at one time or the other with the number of transfusions ranging from 1 to 13 units with a mean of $2.63+$

1.67 units per subject. A patient in the age group 121 to 168 months received greater than eight units of blood

Table VI shows other risk factors studied and shows that;

Circumcision: Two $(66.7 \%)$ of the anti-HCV positive subjects were not circumcised while $1(33.3 \%)$ was 
circumcised but the difference is not significant $(\mathrm{p}=$ $0.3)$.

Sharing of clippers: Sixty six percent of the antiHCV positive subjects shared clippers, while $1(33.3 \%)$ never shared clippers. All the controls that are anti-HCV positive shared clippers. There was no significant difference whether the patient shared clippers or not in both controls and subjects $(\mathrm{p}=$ 0.12 for subjects and 0.41 for controls).

Scarification marks: All the three subjects and the two control patients that are positive for anti-HCV had scarification marks $(p=0.001$ for subjects and 0.02 for controls). Other risk factors looked into were not found in the patients recruited into the study as depicted in table VI.

TABLE I: SEX AND AGE DISTRIBUTION OF THE TOTAL POPULATION STUDIED.

\begin{tabular}{|c|c|c|c|}
\hline & Total & Subjects & Controls \\
\hline & $n(\%)$ & $n(\%)$ & $n(\%)$ \\
\hline \multicolumn{4}{|l|}{ Sex } \\
\hline Male & 93(56) & $50(61)$ & $43(51.2)$ \\
\hline Female & $73(44)$ & $32(39)$ & 41(48.8) \\
\hline Total & 166(100) & $82(100)$ & $84(100)$ \\
\hline \multicolumn{4}{|c|}{ Age group in months } \\
\hline $6-60$ & $60(36.2)$ & $29(35.4)$ & $31(36.9)$ \\
\hline $61-120$ & $52(31.3)$ & 27(32.9) & $25(29.8)$ \\
\hline $121-168$ & $54(32.5)$ & $26(31.7)$ & $28(33.3)$ \\
\hline Mean age & & $95.8+48.7$ & $93.5+54.0^{* *}$ \\
\hline
\end{tabular}

TABLE II: THE ANTI- HCV SEROPOSITIVITY IN THE SUBJECTS AND CONTROLS. Anti-HCV positive Anti-HCV negative Total

\begin{tabular}{|c|c|c|c|c|}
\hline & n(\%) & $\mathbf{n}(\%)$ & $\mathbf{n}(\%)$ & $x^{2}$ \\
\hline Subjects & $3(3.7)$ & $79(96.3)$ & $82(100)$ & \\
\hline Controls & $2(2.4)$ & $82(97.6)$ & $84(100)$ & $\begin{array}{ll}0.23 & 0.68\end{array}$ \\
\hline
\end{tabular}

TABLE III: $\quad$ THE SOCIOECONOMIC CLASSIFICATION OF THE SUBJECTS AND CONTROLS. Subjects Controls

\begin{tabular}{ccllll} 
Social Class & Total & $n(\%)$ & $n(\%)$ & $\chi^{2}$ & $p$ \\
\hline I & 11 & $5(45.5)$ & $6(54.5)$ & 0.18 & 0.67 \\
II & 60 & $22(36.7)$ & $38(63.3)$ & 8.53 & 0.003 \\
III & 70 & $44(62.9)$ & $26(37.1)$ & 9.26 & 0.002 \\
IV & 22 & $10(45.5)$ & $12(54.5)$ & 0.36 & 0.54 \\
V & 3 & $1(66.7)$ & $2(33.3)$ & 0.00 & 1.00 \\
\hline
\end{tabular}

TABLE IV: ANTI-HCV POSITIVITY IN SUBJECTS AND CONTROLS ACCORDING TO SOCIAL CLASS

\begin{tabular}{|c|c|c|c|c|c|c|}
\hline & Subjects & & & Controls & & \\
\hline Social class & $\begin{array}{l}\text { Anti-HCV } \\
\text { positive } \\
n(\%)\end{array}$ & $\begin{array}{l}\text { Anti-HCV } \\
\text { negative } \\
n(\%)\end{array}$ & $\begin{array}{l}\text { Total } \\
N\end{array}$ & $\begin{array}{l}\text { Anti-HCV } \\
\text { positive } \\
n(\%)\end{array}$ & $\begin{array}{l}\text { Anti-HCV } \\
\text { negative } \\
n(\%)\end{array}$ & $\begin{array}{l}\text { Total } \\
N\end{array}$ \\
\hline I & 0 & $5(100)$ & 5 & 0 & $6(100)$ & 6 \\
\hline II & $1(4.5)$ & $21(95.5)$ & 22 & $1(2.6)$ & $37(97.4)$ & 38 \\
\hline III & $1(2.3)$ & 43(97.7) & 44 & $1(3.8)$ & $25(96.2)$ & 26 \\
\hline IV & 0 & 10(100) & 10 & 0 & 12(100) & 12 \\
\hline V & $1(100)$ & 0 & 1 & 0 & $2(100)$ & 2 \\
\hline \multicolumn{7}{|c|}{$\begin{array}{l}\text { Categorised social } \\
\text { class }\end{array}$} \\
\hline Low(III-V) & $2(3.6)$ & $53(96.4)$ & 55 & $1(2.5)$ & $39(97.5)$ & 40 \\
\hline High(I-II) & $1(3.7)$ & $26(96.3)$ & 27 & 1(2.3) & $43(97.7)$ & 44 \\
\hline
\end{tabular}


TABLE V: CORRELATION BETWEEN ANTI-HCV SEROPOSITIVITY AND THE UNITS OF BLOOD TRANSFUSED.

\begin{tabular}{|c|c|c|c|c|c|c|}
\hline & $\begin{array}{l}\text { Anti-HCV } \\
\text { positive }\end{array}$ & $\begin{array}{l}\text { Anti-HCV } \\
\text { negative }\end{array}$ & Total & & & \\
\hline $\begin{array}{l}\text { Units of blood } \\
\text { transfused }\end{array}$ & $n(\%)$ & $n(\%)$ & $N$ & ${ }^{*} \mathrm{OR}$ & $* * \mathrm{CI}$ & p \\
\hline $1-2$ & $1(2.2)$ & $45(97.8)$ & 46 & & & \\
\hline $3-4$ & $2(6.9)$ & $27(93.1)$ & 29 & 0.30 & $0.01-4.54$ & 0.33 \\
\hline 5-8 & 0 & 61(100) & 61 & - & - & - \\
\hline$>8$ & 0 & 1(100) & 1 & & & \\
\hline
\end{tabular}

*=Odds ratio. $\quad * *=95 \%$ Confidence interval.

TABLE VI: THE RISK FACTORS FOR ANTI- HCV POSITIVITY IN THE SUBJECTS AND CONTROLS.

\begin{tabular}{|c|c|c|c|c|c|c|c|c|c|c|}
\hline & Subjects & & & & & Controls & & & & \\
\hline Risk factors & $\begin{array}{l}\text { Positiven } \\
(\%)\end{array}$ & $\begin{array}{c}\text { Negative } n \\
(\%)\end{array}$ & $\begin{array}{l}\text { Total } \\
n(\%)\end{array}$ & $x^{2}$ & $\mathbf{P}$ & $\begin{array}{l}\text { Positive } \\
n(\%)\end{array}$ & $\begin{array}{l}\text { Negative } \\
n(\%)\end{array}$ & $\begin{array}{l}\text { Total } \\
n(\%)\end{array}$ & $x^{2}$ & $\mathbf{p}$ \\
\hline \multicolumn{11}{|l|}{ Circumcision } \\
\hline Circumcised & $1(2.2)$ & $45(97.8)$ & $46(100)$ & & & $2(4.2)$ & $46(95.8)$ & $48(100)$ & & \\
\hline \multicolumn{10}{|l|}{ Not circumcised } & 0.3 \\
\hline \multicolumn{11}{|l|}{ Sharing of clippers } \\
\hline Shared clipper & $2(5.6)$ & $34(94.4)$ & $36(100)$ & & & $2(6.7)$ & 28(93.3) & $30(100)$ & & \\
\hline \multicolumn{11}{|l|}{ Not shared clipper } \\
\hline \multicolumn{11}{|l|}{ Scarification marks } \\
\hline Scarification & $3(30)$ & $7(70)$ & 10(100) & & & $2(16.7)$ & $10(83.3)$ & 12(100) & & \\
\hline No scarification & 0 & $72(100)$ & $72(100)$ & 14.72 & 0.001 & 0 & $72(100)$ & $72(100)$ & 6.17 & 0.02 \\
\hline \multicolumn{11}{|l|}{ Blood transfusion } \\
\hline $\begin{array}{l}\text { Transfused } \\
\text { Not transfused }\end{array}$ & $\begin{array}{l}3(3.7) \\
2(2.4)\end{array}$ & $\begin{array}{l}79(96.3) \\
82(97.6)\end{array}$ & $\begin{array}{l}82(100) \\
84(100)\end{array}$ & 0.23 & 0.68 & & & & & \\
\hline $\begin{array}{l}\text { Tattoo marks } \\
\text { Abuse of drug } \\
\text { Indulging in sexual } \\
\text { activity } \\
\text { Needle sharing }\end{array}$ & $\begin{array}{l}0 \\
0\end{array}$ & $\begin{array}{l}0 \\
0\end{array}$ & & & & $\begin{array}{l}0 \\
0\end{array}$ & $\begin{array}{l}0 \\
0\end{array}$ & & & \\
\hline
\end{tabular}




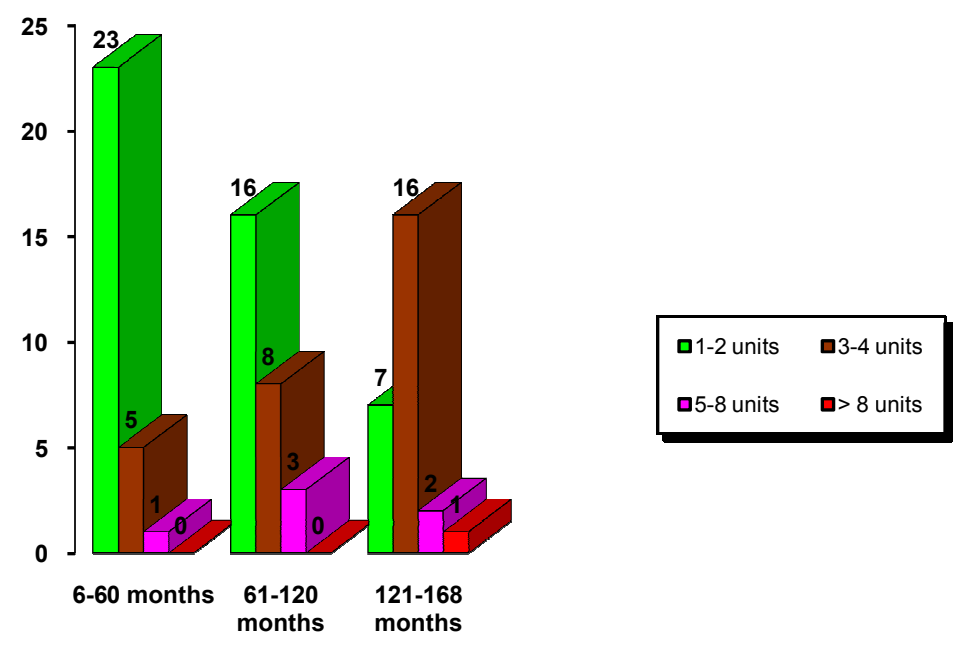

\section{FIGURE 1: BAR CHART SHOWING THE UNITS OF BLOOD TRANSFUSED IN THE DIFFERENT AGE GROUPS} AMONGST THE SUBJECTS.

\section{DISCUSSION}

In this study, the seroprevalence rate of anti-HCV is $3.7 \%$ in the transfused sickle cell anaemia (SCA) patients and $2.4 \%$ in the controls that were not transfused, a finding that is similar to previous reports. 2,4

An overall prevalence of $3 \%$ was detected in sickle cell anaemia patients generally, with a higher prevalence of $3.7 \%$ in transfused patients, and $2.4 \%$ in non-transfused sickle cell anaemia patients. These values parallels the frequency of $\mathrm{HCV}$ infection in the world population in general estimated at $3 \%^{4}$, while the frequency among SCA patients submitted to transfusion of blood or blood derivatives reported in the literature ranges from 2 $30 \%$. $2,5-9,15$ In the present study, the ages of children screened for hepatitis $C$ virus antibody falls between 6 months and one hundred and sixty-eight months with children within the age range six to sixty months having the highest percentage of seropositivity of $36.2 \%$ whilst children between the age of sixty one to a hundred and twenty having the lowest percentage of $31.3 \%$. Sickle cell anaemia patients who received multiple blood transfusions did not appear to be at a greater risk of acquiring hepatitis $C$ virus infection since the prevalence is comparable in the transfused cases and non transfused controls suggesting that blood transfusion may not be the only or major route of transmission.

The patients were evenly distributed in the five social classes and the subjects and controls were comparable except in social classes two and three where the differences in the subjects and controls were statistically significant. Over two-thirds of those that are anti-HCV positive were in the low socioeconomic class, a finding that is similar to other reports from the Niger delta ${ }^{17}$ area of Nigeria and in the USA. ${ }^{18}$ This can be attributed to the poverty and resultant ignorance and poor health seeking behaviour of this group of people.

There was also no correlation in prevalence between multi-transfused and non-transfused sickle cell anaemia patients, a finding that is similar to earlier reports 2,14 but at variance with others, 1,18 that reported a higher prevalence with multi-transfused SCA patients. Since multi-transfused SCA patients did not appear to be at a greater risk, blood transfusion may not be the only or major route of transmission. There was a linear correlation between the prevalence of anti-HCV and increasing number of units of blood transfused and this is similar to the trend in other studies.1,19-21 The highest prevalence was in those who had more than 3 units of blood. This is comparatively higher than those that received more than 10 units of blood in both US studies with seroprevalence of $23 \%$ and $30 \% .16,20$

The higher magnitude of the risk of positivity with each transfusion in the Nigerian studies may suggest that more contaminated blood is being transfused. This is not surprising considering that blood is not usually screened for HCV antibodies, it is therefore pertinent that blood be given only when necessary and blood for transfusion should also be screened for Hepatitis $\mathrm{C}$ virus antibodies.

Tribal marks, male and female circumcision, medicinal and other scarifications, all of which are common practices in this environment correlates well with a high seropositivity. Of the other risk factors considered none of the patients had tattoo marks, abused drugs, indulged in sexual activities 
or shared needles. Some of the patients that were positive for anti-HCV were circumcised, shared clippers but these were not statistically significant.

It is interesting to note that all the 3 subjects and 2 control patients that were positive for anti-HCV had scarification marks for various reasons ranging from family culture to therapeutic indications. Most of the scarifications and sociocultural practices were done by Herbalists using crude methods involving sharp reusable and scientifically unsterilized devices.

It is plausible to suggest that engagement in these activities as verified in the cases that were positive for $\mathrm{HCV}$ antibodies could have exposed these patients to infection with Hepatitis $\mathrm{C}$ virus. This finding is in consonance with an earlier work in adults and blood donors carried out in Ilorin. ${ }^{22}$ There is therefore the need for a larger survey in children to ascertain if this is a possible major route of transmission. Despite the high prevalence of other potential risk factors, only previous scarification marks and previous history of blood transfusion was associated with HCV antibody positivity in this study. Whatever the source of infection, screening of blood and blood products alone may not prevent the transmission of $\mathrm{HCV}$

\section{REFERENCES}

1. Mutimer DJ, Olomu A, Skidmore $\mathrm{S}$ et al. Viral hepatitis in Nigeria sickle cell disease and commercial blood donors. QJ Med 1994; 87: 407-11.

2. Lesi OA and Kehinde MO. Hepatitis C virus infection in patients with sickle cell anaemia at Lagos University Hospital. Nig Postgr Med J 2003; 10: 79-83.

3. Hoognagle JH. Hepatitis C, the clinical spectrum of disease. Hepatology 1997; 26: 5S-20S.

4. Esteban JI, Lopez-Televera JC, Genesca J et al. High Rate of Infectivity and Liver Disease in Blood Donors with Antibodies to Hepatitis C Virus. Ann Intern Med 1999; 15: 443-9.

5. WHO. Hepatitis C WHO Fact Sheet No 164. Available at http:// www.who.int/inffs/en/fact 164.html, 98.

6. Coursaget P, Bourdil C, Kastally R, et al. Prevalence of hepatitis $C$ virus infection in Africa; anti HCV antibodies in the general population and in patients suffering from cirrhosis or primary liver cancer. Res Virol 1990; 141: 449-54.

7. Choo QL, Weiner AJ, Overby LR et al. Hepatitis $C$ virus: The major causative agent of viral non-A, non-B hepatitis. $\mathrm{Br}$ Med Bull 1990; 46: 423-41.

8. Finleyson MD, Hayes PC, Simpson KJ. Diseases of the liver and biliary system. In: Christopher H ed. Davidson's Principle infection effectively in this environment. Increasing awareness of the disease and its route of transmission, adequate enlightenment of the general population as well as health care workers on safe medical practices could make a significant impact on the spread of $\mathrm{HCV}$ infection. Furthermore, premarital antenatal counseling and screening for sickle cell disease will contribute to a decrease in prevalence through a corresponding decrease in the sickle cell gene frequency.

Transmission of $\mathrm{HCV}$ infection resulting from unsafe injections is being increasingly described and recent epidemiology in developing countries suggests that this and other sporadic non transfusion related routes which had previously been grossly underestimated, maybe the important routes of $\mathrm{HCV}$ transmission ${ }^{2}$ In Japan, tattooing, scarification marks and the use of unsterilized needles in the practice of folk medicine including acupuncture and related techniques has been documented as significant routes of transmission. All these are in agreement with the findings of this study.

Larger studies are necessary to address the role of other risk factors like scarification marking, unsafe injections, use of public clippers as well as blood transfusion in the transmission of $\mathrm{HCV}$ infection.

and Practice of Medicine. Edinburgh: Churchill Livingstone (Publishers) Ltd, 1999: 683-736.

9. Choo QL, Kuo G, Weiner AJ et al. Isolation of A cDNA clone derived from a blood borne non-A, non-B viral hepatitis genome. Science.1989; 244: 359-62.

10. Kuo G, Choo QL, Alter HJ et al. An Essay for Circulating Antibodies to a Major Etiologic Virus of Human non-A, non-B Hepatitis. Science, 1989; 244: 362-64.

11. Donahue JG, Munoz A, Ness PM et al. The declining risk of post-transfusion hepatitis C virus infection. $N$ Engl J Med 1992; 327: 369-73.

12. Schreiber GB, Busch MP, Kleinman SH et al. The risk of transfusion -transmitted viral infections. N Engl J Med 1996; 334: 1685-90.

13. Bhattacharya DK, Bhattacharjee S, M De Lahiri P De. Prevalence of hepatitis C in transfusion dependent thalassaemics and haemophiliacs. Ind $j$ Med Res (B) 1991; 94:430-32.

14. Adewuyi JO. Prevalence of antibodies to hepatitis $C$ virus among normal blood donors and multi-transfused sickle-cell anaemia patients in Nigeria. Tropical Doctor 1996; 26: 29-30.

15. Akinyaju OA. A profile of sickle cell disease in Nigeria. Ann NY Acad Sci 1989; 565: 126-36. 
16. Kane, A., Lloyd, J., Zaffram, M., Simonsen, L.,Kane, M., et al. Transmission of Hepatitis B., Hepatitis C and Human Immunodeficiency viruses through unsafe injections in the developing world. Model based regional estimates. WHO bull. 1999; 77: 801-807.

17. Ejele OA, Nwauche CA, Erhabor O. Seroprevalence of Hepatitis C Virus in the Niger Delta of Nigeria. Nig Postgr Med. J 2006; 13: 103-06.

anaemia. J Clin Gastroenterol 1994; 18: 206-9.

18. Thomas DC, Zerilman JM, Alter HJ. Sexual transmission of hepatitis $\mathrm{C}$ among patients attending Baltimore sexually transmitted diseases clinic: An analysis of 309 sexual partnerships. J Infec. Dis. 1995; 171: 768-75.

19. Hasan MF, Marsh F, Posner G. et al. Chronic hepatitis $\mathrm{C}$ in patients with sickle cell disease. Am J Gastroenterol 1996; 91: 1204-6.
20. De Vault KR, Friedman LS, Westerberg S et al. Hepatitis C in sickle cell anaemia. J Clin Gastroenterol 1994; 18: 206-9.

21. Torres MCMR, Pereira LMMB, Ximenes RAA et al. Hepatitis C virus infection in a Brazilian population with sickle- cell anaemia. Braz J Med Biol Res 2003; 36: 32329.

22. Agbede OO, Iseniyi JO, Ojuawo A, et al. Risk factors and seroprevalence of hepatitis $C$ antibody in mothers and their pre-school age children in Ilorin. Afr. J Clin. Exper. Microbiol. 2006; 7:153-7. 